\title{
EFFECT OF POULTRY MANURE INCORPORATED WITH NITROGENOUS AND SULFUR FERTILIZER ON THE GROWTH, YIELD, CHLOROPHYLL AND NUTRIENT CONTENTS OF RICE var. BRRI dhan33
}

\author{
D. Sarker ${ }^{1}$, S.Mazumder ${ }^{2}$, S.Kundu ${ }^{3}$, F.Akter ${ }^{4}$, and S.K.Paul ${ }^{5}$ \\ ${ }^{1}$ Department of Agricultural Chemistry, Sher-e-Bangla Agricultural University, Dhaka-1207, Bangladesh \\ 2Sher-e-Bangla Nagar Adorsha Mohila College, Dhaka-1207, Bangladesh \\ ${ }^{3}$ Planning and Evaluation Division, Bangladesh Agricultural Research Institute, Joydebpur, Gazipur-1701, Bangladesh \\ ${ }^{4}$ Planning and Evaluation Division, Bangladesh Agricultural Research Institute, Joydebpur, Gazipur-1701, Bangladesh \\ ${ }^{5}$ Agronomy Division, Bangladesh Agricultural Research Institute, Joydebpur, Gazipur-1701, Bangladesh.
}

Key Word: Poultry Manure, Nitrogen, Sulfur, Rice var. BRRI dhan33.

\begin{abstract}
The experiment was conducted in the farm of Sher-e-Bangla Agricultural University, Dhaka, Bangladesh during the period from August to December 2012 to study the effect of various combinations of organic manure and inorganic fertilizer on the growth, yield, chlorophyll and nutrient content of rice var. BRRI dhan33. The treatment consists of $\mathrm{T}_{1}: 100 \%$ Inorganic fertilizer (Recommended dose) +5 ton poultry manure $(\mathrm{PM}) /$ ha $, \mathrm{T}_{2}: 75 \% \mathrm{~N}$ of recommended dose +5 ton $\mathrm{PM} / \mathrm{ha}, \mathrm{T}_{3}: 50 \% \mathrm{~N}$ of recommended dose +5 ton $\mathrm{PM} /$ ha, $\mathrm{T}_{4}: 25 \% \mathrm{~N}$ of recommended dose +5 ton $\mathrm{PM}$ /ha, $\mathrm{T}_{5}: 75 \% \mathrm{~S}$ of recommended dose +5 ton $\mathrm{PM} / \mathrm{ha}, \mathrm{T}_{6}: 50 \% \mathrm{~S}$ of recommended dose +5 ton PM /ha, $\mathrm{T}_{7}: 25 \% \mathrm{~S}$ of recommended dose +5 ton PM $/$ ha, $\mathrm{T}_{8}: 100 \%$ Inorganic fertilizer and $\mathrm{T}_{9}: 5$ ton PM /ha. Significant variation was found in growth and yield parameters as well as in chlorophyll content and nutrient content of aman rice. The most of the growth parameters ( plant height, leaf length and diameter, leaf number and total tiller plant ${ }^{-1}$ ) results were found better in 100\% Inorganic fertilizer +5 ton PM ha ${ }^{-1}$ which was statistically similar with $75 \%$ of recommended dose of S + 5 ton PM ha-1, $75 \%$ of recommended dose of $\mathrm{N}+5$ ton PM ha-1 and followed by $50 \%$ of recommended dose of $\mathrm{S}+5$ ton $\mathrm{PM} \mathrm{ha}^{-1}$, respectively while the lowest from 5 ton/ha PM treatment. On the other hand, significantly higher chlorophyll "a", "b" and total chlorophyll content were recorded in $100 \%$ Inorganic fertilizer +5 ton PM ha' 1 and it was closely followed by $75 \%$ of recommended dose of $\mathrm{N}+5$ ton $\mathrm{PM} \mathrm{ha}^{-1}$ and lowest in 5 ton PM ha ${ }^{-1}$. Number of effective tillers plant ${ }^{-1}$, panicle length, number of rachis plant ${ }^{-1}$, filled grain plant ${ }^{-1}$ and fresh weight of plant were highest in $100 \%$ Inorganic fertilizer +5 ton PM /ha and it was either statistically similar or closely followed by $75 \%$ of recommended dose of $S+5$ ton PM ha ${ }^{-1}$. Higher grain yield (4.18 t ha-1) was recorded in $T_{1}$ which was statistically similar with $T_{5}\left(4.13 \mathrm{t} \mathrm{ha}^{-1}\right)$ whereas lowest grain yield ( $\left.3.67 \mathrm{t} \mathrm{ha}^{-1}\right)$ was from sole PM. Similarly, N content in grain and $\mathrm{N}, \mathrm{K}$ content in straw were also showed similar trend. S content in grain and $\mathrm{P}, \mathrm{S}$ content in straw were higher in $75 \%$ of recommended dose of $\mathrm{S}+5$ ton $\mathrm{PM} /$ ha compared to other fertilizer treatments. Lowest $\mathrm{N}$ and $\mathrm{S}$ content in grain and $\mathrm{N}, \mathrm{P}, \mathrm{K}$, $\mathrm{S}$ content in straw were found from the treatment using poultry manure only.
\end{abstract}

\section{Introduction}

Rice is intensively cultivated in Bangladesh covering about $80 \%$ of arable land. Rice alone constitutes $95 \%$ of the food grain production in Bangladesh. Unfortunately, the yield of rice is low considering the other rice growing countries like South Korea and Japan where the average yield is 7.00 and $6.22 \mathrm{t} \mathrm{ha}^{-1}$, respectively (FAO, 1999. A suitable combination of 
Sarker et al.

organic and inorganic sources of nutrients is necessary for sustainable agriculture that can ensure food production with high quality. Nambiar (1991) views that integrated use of organic manure and chemical fertilizers would be quite promising not only in providing greater stability in production, but also in maintaining better soil fertility. Meelu and Singh (1991) showed that $4 \mathrm{t} \mathrm{ha}^{-1}$ poultry manure along with $60 \mathrm{~kg} \mathrm{~N} / \mathrm{ha}$ as urea produce grain yield of crop similar to that with $120 \mathrm{~kg} \mathrm{~N} / \mathrm{ha}$ as urea alone. Depleted soil fertility is a major constrain to higher crop production in Bangladesh. Applications of both chemical and organic fertilizers need to be applied for the improvement of soil physical properties and supply of essential plant nutrients for higher yield. (Sarvanan et al., 1987). Rice is very responsive to $\mathrm{N}$ fertilization and high yield potential of modern varieties cannot be realized without $\mathrm{N}$ supply to the plant during the entire growing season. Nitrogen has quickest and remarkable effect on cereals production (Brady, 1999). Sulphur, one of the most important nutrients for all plants and animals, is considered as the fourth major nutrient after nitrogen, phosphorous and potassium for agricultural crop production. It is involved in chlorophyll formation, activation of enzymes and is a part of vitamins biotin and thiamine (B1) (Hegde and Sudhakara Babu, 2007). Poultry manure is superior to the other farmyard manure as a source of nitrogen supply. All the nitrogen in poultry manure is not in available from initially. Hence, soils treated with poultry manure are less susceptible to nitrogen leaching since the vegetables grown utilize nitrate as they are produced (Maynard, 1984). Considering the above facts, the experiment was under taken to find out the response of PM along with chemical fertilizers for rice var. BRRI dhan33.

\section{Materials and Methods}

The experiment was conducted in the farm of Sher-e-Bangla Agricultural University, Dhaka1207, Bangladesh during the period from August to December 2012. The experimental area is located at 23.41' $\mathrm{N}$ and 90.22' E latitude and at an altitude of $8.6 \mathrm{~m}$ from the sea level. The soil of the experimental field belongs to the Tejgaon series under the Agro-ecological Zone, Madhupur Tract (AEZ- 28) and the General Soil Type is Deep Red Brown Terrace Soils. The experiment was laid out in Randomized Complete Block Design (RCBD) with three replications. Rice var. BRRI dhan33 was used in the experiment. The Treatments were: $T_{1}=100 \%$ Inorganic fertilizer (Recommended dose) +5 ton poultry manure/ha, $\mathrm{T}_{2}=75 \% \mathrm{~N}$ of the recommended dose +5 ton poultry manure/ha, $\mathrm{T}_{3=} 50 \% \mathrm{~N}$ of the recommended dose +5 ton poultry manure/ha, $\mathrm{T}_{4}=25 \% \mathrm{~N}$ of the recommended dose +5 ton poultry manure/ha, $\mathrm{T}_{5}: 75 \% \mathrm{~S}$ of the recommended dose +5 ton poultry manure/ha, $\mathrm{T}_{6}: 50 \% \mathrm{~S}$ of the recommended dose +5 ton poultry manure/ha, $\mathrm{T}_{7}: 25 \% \mathrm{~S}$ of the recommended dose +5 ton poultry manure/ha, $\mathrm{T}_{8}: 100 \%$ inorganic fertilizer, $\mathrm{T}_{9}: 5$ ton poultry manure/ha. The amounts of $\mathrm{N}, \mathrm{P}, \mathrm{K}, \mathrm{S}$ and $\mathrm{Zn}$ fertilizers required per plot were calculated as per the treatments. Poultry manure was used @ rate of 5 ton/ha and was applied before four days of final land preparation. Forty days old seedlings of BRRI dhan33 were transplanted on $21^{\text {st }}$ August, 2012. All other intercultural operation was done as per requirement. The crop was harvested at full maturity when $80-90 \%$ on 27 December, 2012. The data collected on different parameters were statistically and the mean differences among the treatments were compared by Duncan's Multiple Range Test (DMRT) test at 5\% level of significance. Nitrogen was determined by micro kjeldahl method (Jackson, 1973).

Amount of chlorophyll were calculated using the following equations/formula (Witham, 1986):

Chlorophyll a $(\mathrm{mg} / \mathrm{g})=\left[12.7\left(\mathrm{OD}_{663}\right)-2.69\left(\mathrm{OD}_{645}\right)\right] \mathrm{V} / 1000 \mathrm{~W}$

Chlorophyll b $(\mathrm{mg} / \mathrm{g})=\left[22.9\left(\mathrm{OD}_{645}\right)-4.68\left(\mathrm{OD}_{663}\right)\right] \mathrm{V} / 1000 \mathrm{~W}$

Chlorophyll $\mathrm{a}+\mathrm{b}(\mathrm{mg} / \mathrm{g})=\left[20.2\left(\mathrm{OD}_{645}\right)-8.02\left(\mathrm{OD}_{663}\right)\right] \mathrm{V} / 1000 \mathrm{~W}$ 
Where,

$\mathrm{OD}=$ Optical density regarding of the chlorophyll extract at the specific indicated wavelength (645 and 663nm)

$\mathrm{V}=$ Final volume of the $80 \%$ acetone chlorophyll extract $(\mathrm{ml})$

$\mathrm{W}=$ Fresh weight in gram of the tissue extracted

\section{Results and Discussion}

The results of different growth parameters, chlorophyll contents, yield attributes, yield and nutrient concentrations in the straw and grains of rice were found significant and summarized below

\section{Plant height}

The data on plant height of rice at different growth stages as influenced by organic and inorganic fertilizers are presented in Fig.1. The plant height at 30 days after transplanting (DAT) differed significantly due to different treatments where higher plant height $(59.4 \mathrm{~cm})$ was recorded in $T_{1}$ and it was statistically similar with $T_{5}(57.6 \mathrm{~cm})$ and $T_{8}(57.6 \mathrm{~cm})$. Lowest plant height at 30 DAT $(48.4 \mathrm{~cm})$ was found from $\mathrm{T}_{9}$. The plant height at 60 days after transplanting (DAT) also differed significantly due to different treatment where maximum plant height $(103.6 \mathrm{~cm})$ was recorded in $T_{5}$ and it was closely followed by $T_{1}(100.1 \mathrm{~cm})$ and $T_{2}$ $(99.5 \mathrm{~cm})$. Lowest plant height at 60 DAT $(91.4 \mathrm{~cm})$ was found from the treatment using sole poultry manure. At harvest, plant height also showed significant where maximum plant height $(104.6 \mathrm{~cm})$ was recorded in $T_{5}$ and it was closely followed by $T_{1}(102.2 \mathrm{~cm})$ and $T_{2}(101.0$ $\mathrm{cm})$. Lowest plant height at harvest $(93.2 \mathrm{~cm}$ ) was found from the treatment using sole poultry manure. The results showed that combination of organic and inorganic fertilizers significantly increased the plant height than sole use of inorganic fertilizer and then that of organic manure. Combination of organic and inorganic fertilizers was found better by Umanah et al. (2003) in upland rice and Channabasavanna (2003) in wetland rice than only inorganic fertilizers.

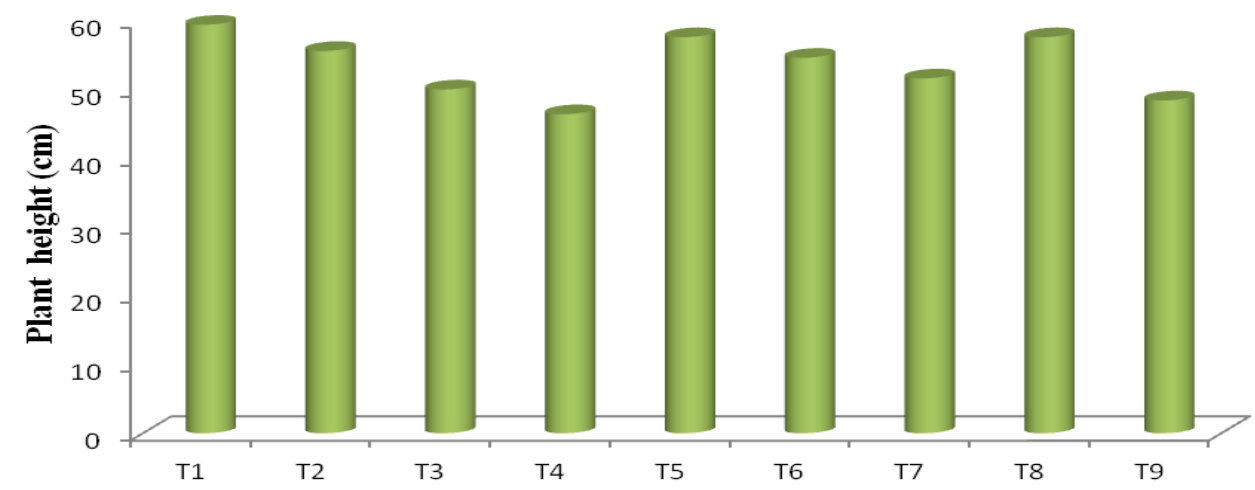

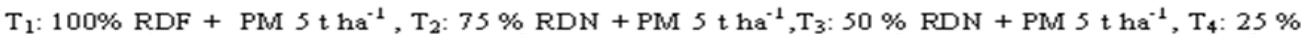
$\mathrm{RDN}+\mathrm{PM} 5 \mathrm{tha}^{-1}, \mathrm{~T}_{5}: 75 \%$ RDS + PM $5 \mathrm{tha}^{-1}, \mathrm{~T}_{6}: 50 \%$ RDS + PM $5 \mathrm{tha}^{-1}, \mathrm{~T}_{7}: 25 \%$ RDS + PM $5 \mathrm{tha}^{-1}, \mathrm{~T}_{8}:$ $100 \%$ RDF, $\mathrm{T}_{9}$ : PM $5 \mathrm{t} \mathrm{ha}^{-1}$

Fig. 1(a). Effect of different combinations of organic and inorganic fertilizer on plant height of BRRI dhan33 (30 DAT) 
Sarker et al.

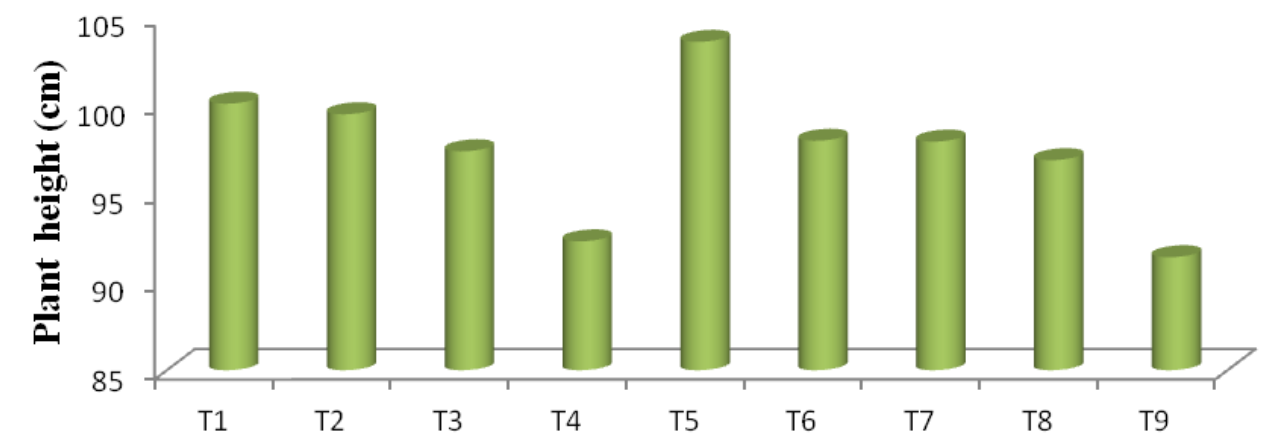

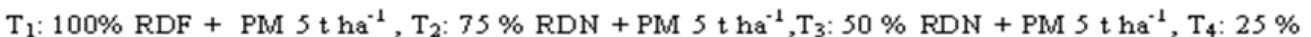
$\mathrm{RDN}+\mathrm{PM} 5 \mathrm{tha}^{-1}, \mathrm{~T}_{5}: 75 \% \operatorname{RDS}+\mathrm{PM} 5 \mathrm{tha}^{-1}, \mathrm{~T}_{6}: 50 \%$ RDS + PM $5 \mathrm{tha}^{-1}, \mathrm{~T}_{7}: 25 \% \operatorname{RDS}+\mathrm{PM}^{2} 5 \mathrm{tha} \mathrm{h}^{-1}, \mathrm{~T}_{8}$ : $100 \%$ RDF, T9: PM $^{2}$ t ha ${ }^{-1}$

Fig. 1(b). Effect of different combinations of organic and inorganic fertilizer on plant height of BRRI dhan33 (60 DAT)

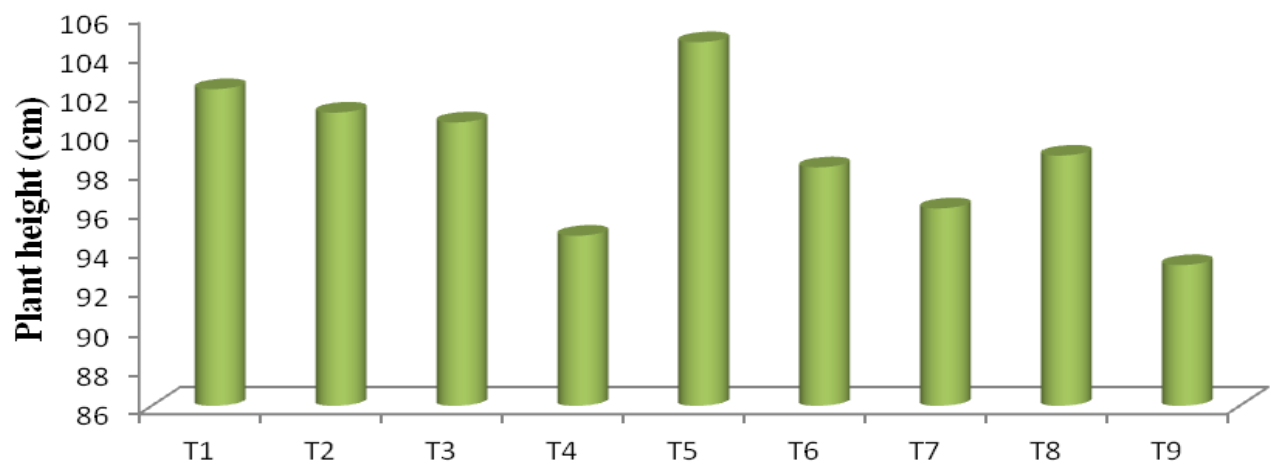

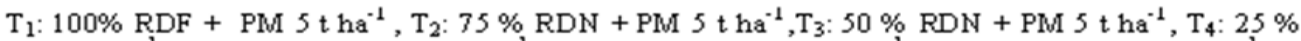
$\mathrm{RDN}+\mathrm{PM} 5 \mathrm{tha}^{-1}, \mathrm{~T}_{5}: 75 \%$ RDS + PM $5 \mathrm{tha}^{-1}, \mathrm{~T}_{6}: 50 \%$ RDS + PM $5 \mathrm{tha}^{-1}, \mathrm{~T}_{7}: 25 \% \operatorname{RDS}+\mathrm{PM}^{\prime} 5 \mathrm{tha}^{-1}, \mathrm{~T}_{8}:$ $100 \%$ RDF, T9: PM $5 \mathrm{tha}^{-1}$

Fig. 1(c). Effect of different combinations of organic and inorganic fertilizer on plant height of BRRI dhan33 (at harvest)

\section{Number of leaves}

The data on number of leaves plant ${ }^{-1}$ of rice at different growth stages as influenced by organic and inorganic fertilizers Fig. 4 ( $\mathrm{a}, \mathrm{b} \& \mathrm{c}$ ). The number of leaves plant ${ }^{-1}$ at 30, 60 DAT and at harvest differed significantly due to different treatments. Significantly higher number of leaves plant $^{-1}$ (4.1) was recorded in $T_{1}$ which was statistically similar to $T_{2}$ (3.9). Lowest number of leaves plant ${ }^{-1}$ at harvest (3.41) was found from the treatment using only poultry manure .Combination of organic and inorganic fertilizers significantly increased the number of leaves plant $^{-1}$ than sole. Ndaeyo et al. (2008) showed that higher NPK (15:15:15) fertilizer significantly increased number of leaves. 


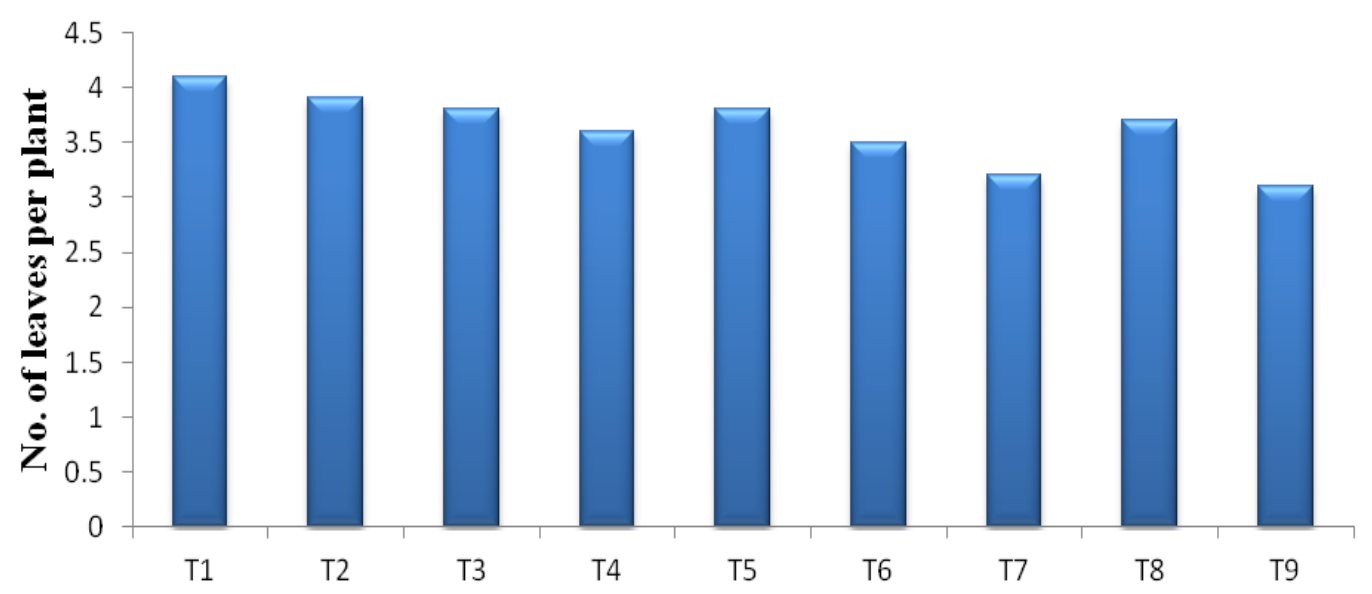

$\mathrm{T}_{1}: 100 \%$ RDF + PM 5 tha ${ }^{-1}, \mathrm{~T}_{2}: 75 \%$ RDN + PM $5 \mathrm{tha}^{-1}, \mathrm{~T}_{3}: 50 \%$ RDN + PM $5 \mathrm{tha}^{-1}, \mathrm{~T}_{4}: 25 \%$ RDN + PM 5 tha ${ }^{-1}, \mathrm{~T}_{5}: 75 \%$ RDS + PM 5 tha ${ }^{-1}, \mathrm{~T}_{6}: 50 \%$ RDS + PM 5 tha ${ }^{-1}, \mathrm{~T}_{7}: 25 \%$ RDS + PM 5 tha ${ }^{-1}, \mathrm{~T}_{8}:$ $100 \%$ RDF, $\mathrm{T}_{9}:$ PM 5 tha ${ }^{-1}$

Fig. 2(a). Effect of different combinations of organic and inorganic fertilizer on number of leaves plant $^{-1}$ of BRRI dhan33 (30 DAT)

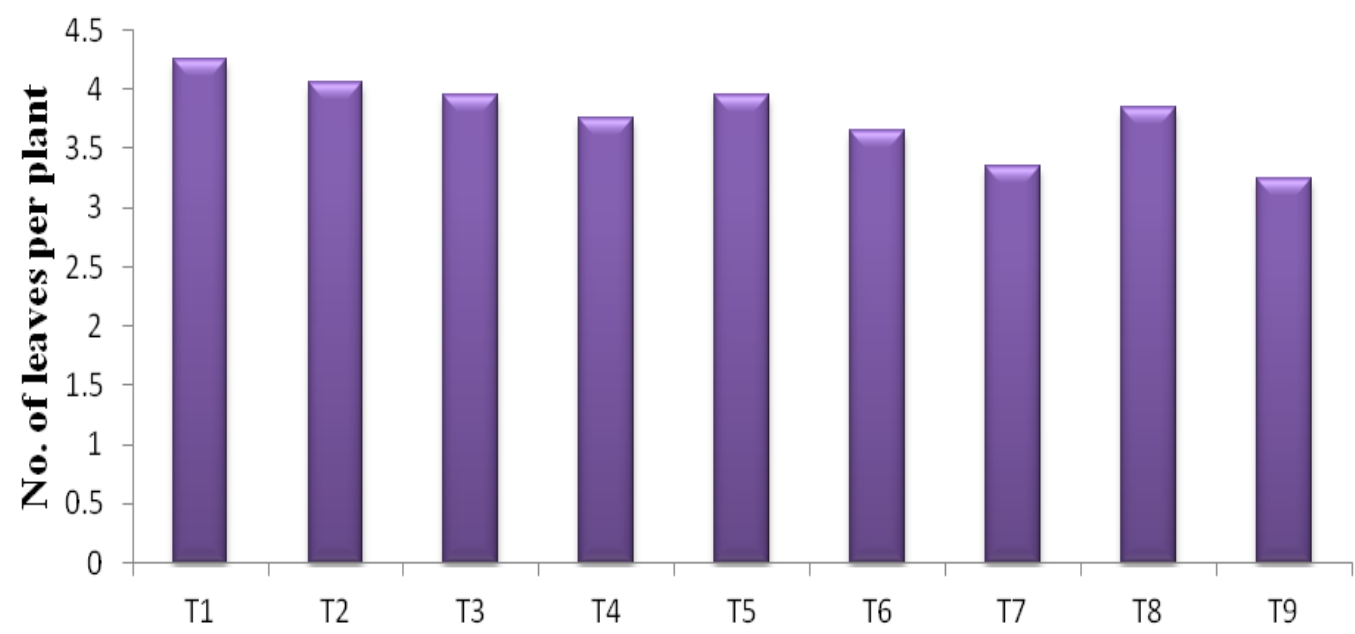

$\mathrm{T}_{1}: 100 \%$ RDF + PM $5 \mathrm{tha}^{-1}, \mathrm{~T}_{2}: 75 \%$ RDN + PM 5 tha ${ }^{-1}, \mathrm{~T}_{3}: 50 \%$ RDN + PM 5 tha ${ }^{-1}, \mathrm{~T}_{4}: 25 \%$ RDN + PM 5 tha $a^{-1}, \mathrm{~T}_{5}: 75 \%$ RDS + PM 5 tha ${ }^{-1}, \mathrm{~T}_{6}: 50 \%$ RDS + PM 5 tha ${ }^{-1}, \mathrm{~T}_{7}: 25 \%$ RDS + PM 5 tha ${ }^{-1}, \mathrm{~T}_{8}:$ $100 \%$ RDF, $\mathrm{T}_{9}$ : PM 5 tha $^{-1}$

Fig. 2(b). Effect of different combinations of organic and inorganic fertilizer on number of leaves plant ${ }^{-1}$ of BRRI dhan33 (60 DAT) 
Sarker et al.

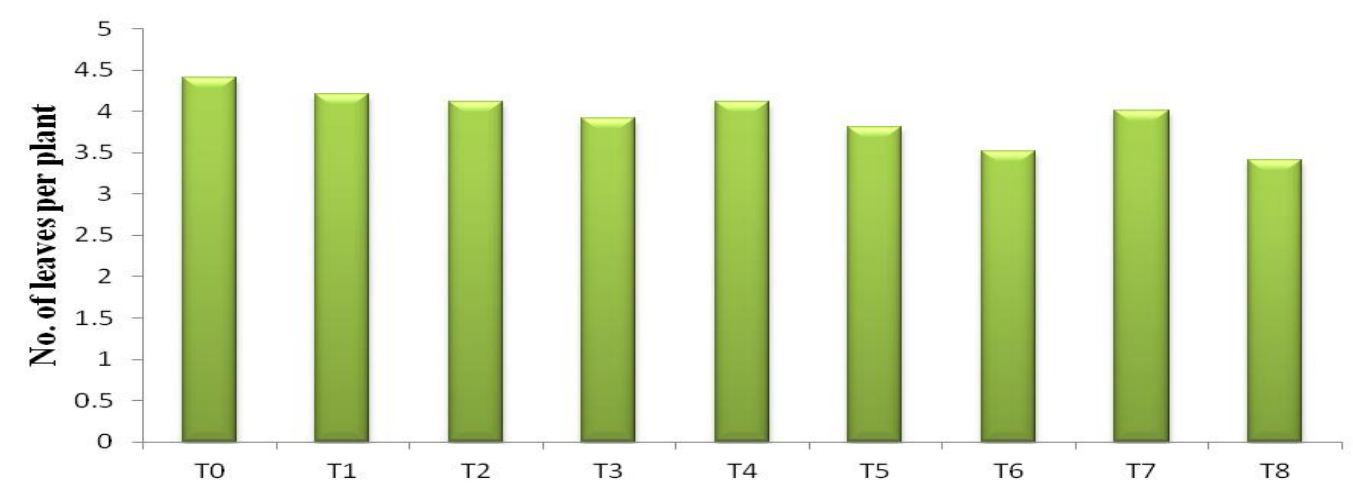

$\mathrm{T}_{1}: 100 \% \mathrm{RDF}+\mathrm{PM} 5 \mathrm{tha} \mathrm{h}^{-1}, \mathrm{~T}_{2}: 75 \% \mathrm{RDN}+\mathrm{PM} 5 \mathrm{tha} \mathrm{h}^{-1}, \mathrm{~T}_{3}: 50 \% \mathrm{RDN}+\mathrm{PM} 5 \mathrm{tha}, \mathrm{T}_{4}: 25 \%$ $\mathrm{RDN}+\mathrm{PM} 5 \mathrm{tha} \mathrm{h}^{-1}, \mathrm{~T}_{5}: 75 \%$ RDS + PM $5 \mathrm{tha}^{-1}, \mathrm{~T}_{6}: 50 \%$ RDS + PM $5 \mathrm{tha}^{-1}, \mathrm{~T}_{7}: 25 \%$ RDS + PM 5 tha ${ }^{-1}, \mathrm{~T}_{8}:$ $100 \%$ RDF, $\mathrm{T}_{9}$ : PM $5 \mathrm{tha}^{-1}$

Fig. 2 (c). Effect of different combinations of organic and inorganic fertilizer on number of leaves plant ${ }^{-1}$ of BRRI dhan33 (at harvest)

\section{Number of effective and non-effective tillers at harvest}

The data on number of effective and non-effective tillers tillers plant ${ }^{-1}$ of rice at harvest as influenced by organic and inorganic fertilizers in Fig. 6 (a \& b). The highest number of effective tillers plant ${ }^{-1}$ (18) was recorded in $T_{1}$ while lowest number of effective tillers plant ${ }^{-1}$ at harvest (12) using sole poultry manure. The number of non-effective tillers plant ${ }^{-1}$ at harvest also differed significantly due to different treatments. Highest number of non-effective tillers plant ${ }^{-1}$ (5) was recorded in $T_{8}$ and lowest number at harvest (2) from the treatment using $T_{5}$ .Combination of organic and inorganic fertilizers significantly increased the number of effective and decreased the number of non-effective tillers plant ${ }^{-1}$ than sole use of inorganic fertilizer and than that of organic manure. Amin et al. (2004) found that increased fertilizer dose of NPK increase number of total tillers plant ${ }^{-1}$.

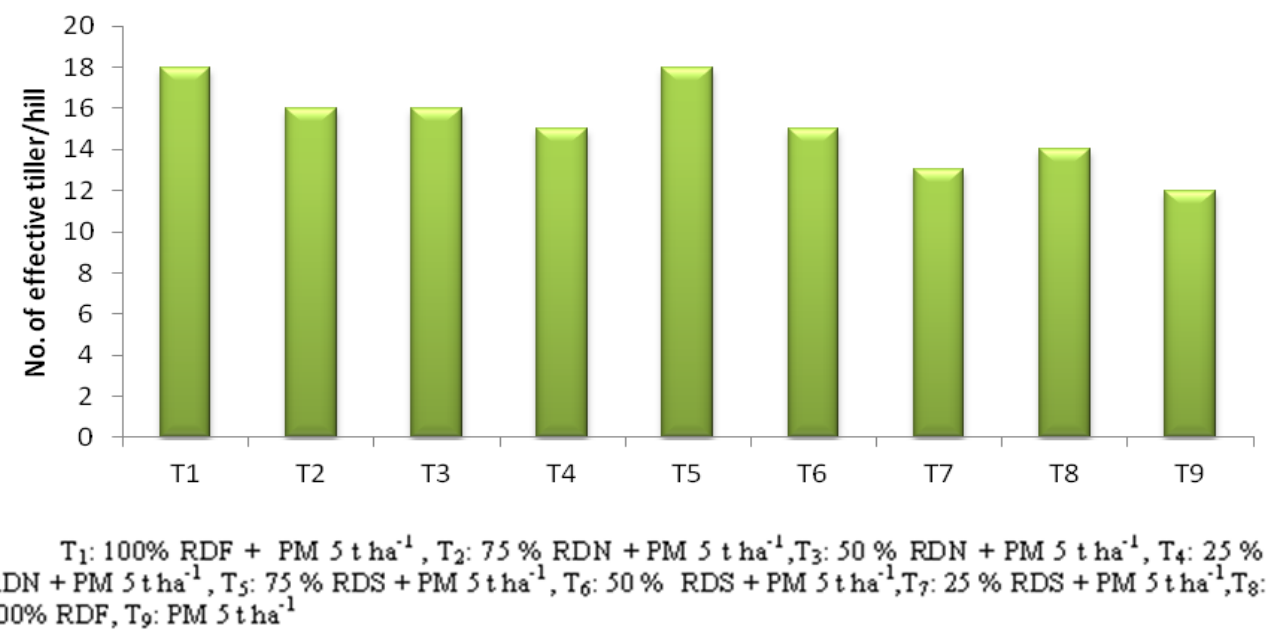

Fig. 3(a). Effect of different combinations of organic and inorganic fertilizer on number of effective tillers plant ${ }^{-1}$ of BRRI dhan33 


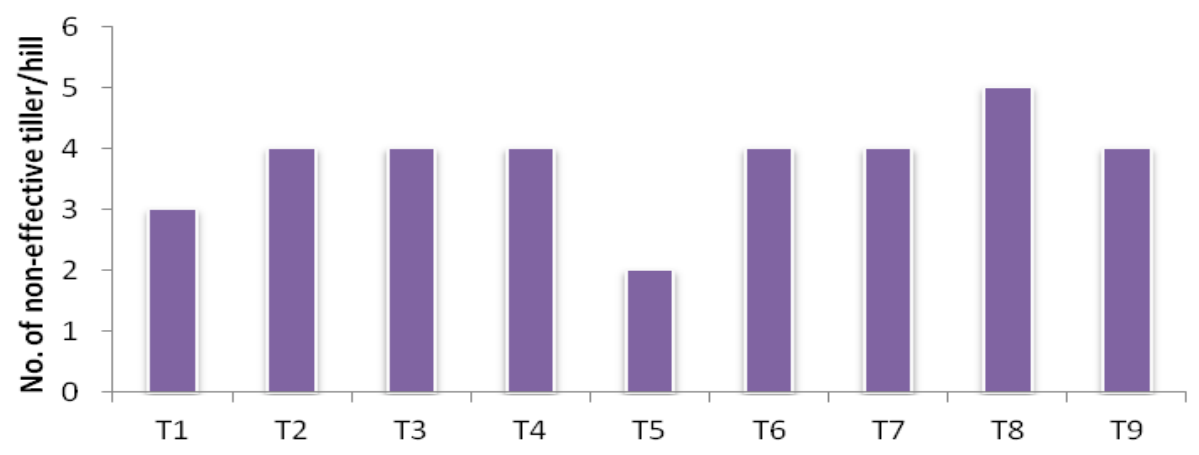

$\mathrm{T}_{1}: 100 \% \mathrm{RDF}+\mathrm{PM} 5 \mathrm{tha}{ }^{-1}, \mathrm{~T}_{2}: 75 \% \mathrm{RDN}+\mathrm{PM} 5 \mathrm{tha} \mathrm{a}^{-1}, \mathrm{~T}_{3}: 50 \% \mathrm{RDN}+\mathrm{PM} 5 \mathrm{tha} \mathrm{a}^{-1}, \mathrm{~T}_{4}: 25 \%$ RDN + PM $5 t_{\text {ha }}{ }^{-1}, \mathrm{~T}_{5}: 75 \%$ RDS + PM $5 \mathrm{tha}^{-1}, \mathrm{~T}_{6}: 50 \%$ RDS + PM $5 \mathrm{tha}^{-1}, \mathrm{~T}_{7}: 25 \%$ RDS + PM $5 \mathrm{tha}^{-1}, \mathrm{~T}_{8}:$ $100 \%$ RDF, $\mathrm{T}_{9}$ : PM 5 tha $^{-1}$

Fig. 3(b). Effect of different combinations of organic and inorganic fertilizer on number of noneffective tillers plant ${ }^{-1}$ of BRRI dhan33

\section{Number of filled grain per plant}

Significantly higher number of filled grain plant ${ }^{-1}$ (170) was recorded in $T_{1}$ (100\% Inorganic fertilizer +5 ton poultry manure/ha) and it was closely followed by $T_{5}$ (169) and $T_{2}$ (168). Lowest number of filled grain plant ${ }^{-1}(153)$ was found from the treatment using sole poultry manure (Fig. 4.9).

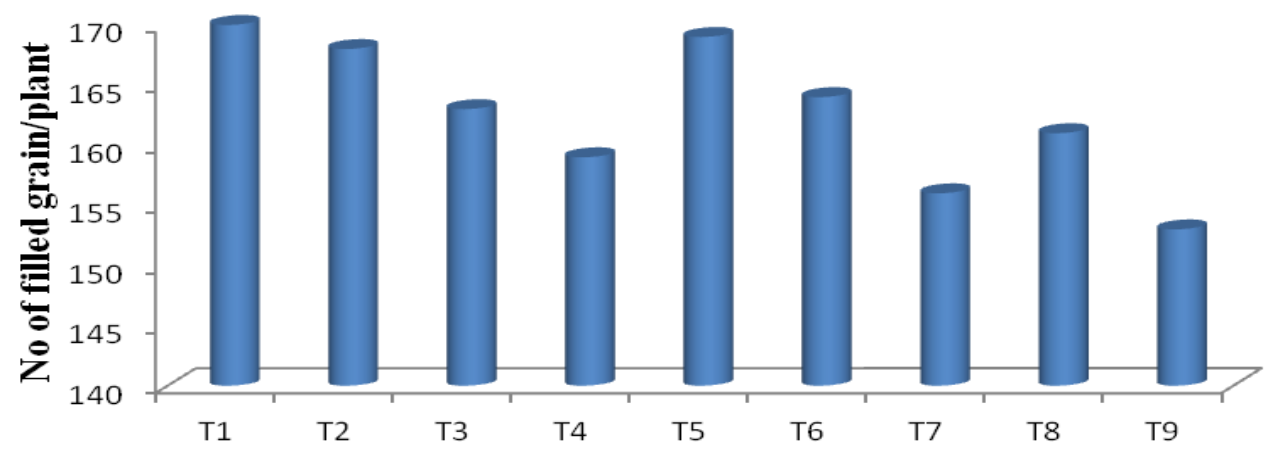

$\mathrm{T}_{1}: 100 \% \mathrm{RDF}+\mathrm{PM} 5 \mathrm{tha} \mathrm{C}^{-1}, \mathrm{~T}_{2}: 75 \% \mathrm{RDN}+\mathrm{PM} 5 \mathrm{tha} \mathrm{R}^{-1}, \mathrm{~T}_{3}: 50 \% \mathrm{RDN}+\mathrm{PM} 5 \mathrm{tha} \mathrm{C}^{-1}, \mathrm{~T}_{4}: 25 \%$ $\mathrm{RDN}+\mathrm{PM} 5 \mathrm{tha} \mathrm{T}^{-1}, \mathrm{~T}_{5}: 75 \%$ RDS + PM $5 \mathrm{tha}^{-1}, \mathrm{~T}_{6}: 50 \%$ RDS + PM $5 \mathrm{tha}^{-1}, \mathrm{~T}_{7}: 25 \%$ RDS + PM $5 \mathrm{tha}^{-1}, \mathrm{~T}_{8}:$ $100 \%$ RDF, $\mathrm{T}_{9}$ : PM $5 \mathrm{t} \mathrm{ha}^{-1}$

Fig. 4. Effect of different combinations of organic and inorganic fertilizer on number of filled grain plant ${ }^{-1}$ of BRRI dhan33

\section{Number of unfilled grain per plant}

The number of unfilled grain plant ${ }^{-1}$ differed significantly due to different combinations of organic and inorganic fertilizer (Fig. 10). Significantly lower number of unfilled grain plant ${ }^{-1}$ (39) was recorded in $T_{1}$ and it was closely followed by $T_{5}(41)$. Highest number of unfilled grain plant $^{-1}$ (47) was found from the treatment using sole poultry manure. 
Sarker et al.

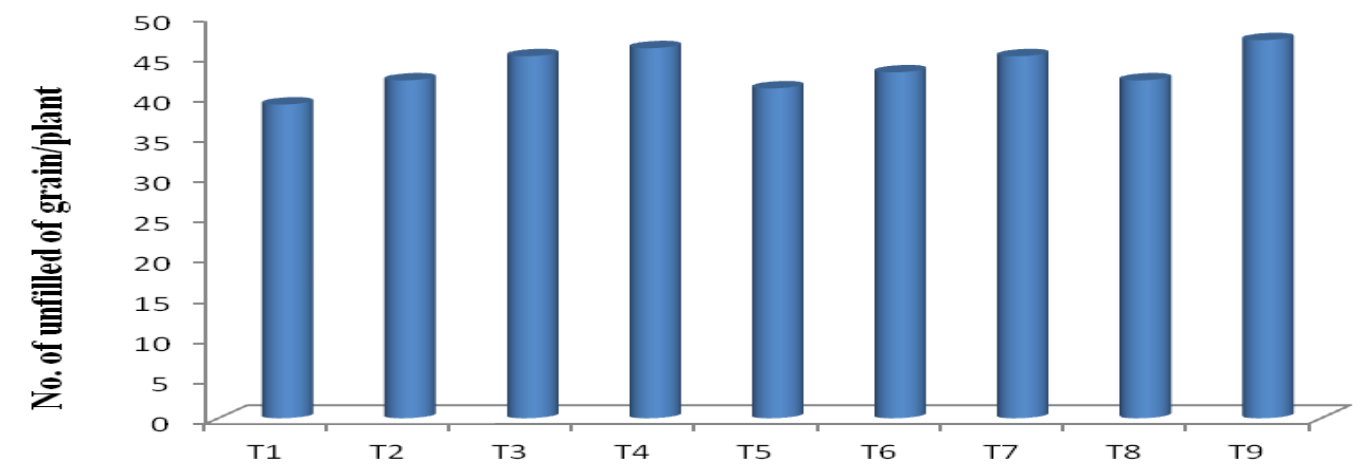

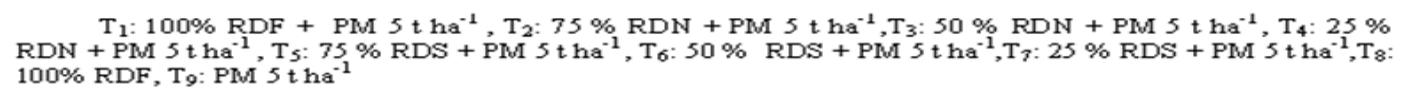

Fig. 5. Effect of different combinations of organic and inorganic fertilizer on number of unfilled grain plant ${ }^{-1}$ of BRRI dhan33

\section{Grain yield}

The higher grain yield $\left(4.18 \mathrm{t} \mathrm{ha}^{-1}\right)$ was recorded in $\mathrm{T}_{1}$ where lowest grain yield $\left(3.67 \mathrm{t} \mathrm{ha} \mathrm{a}^{-1}\right)$ was found from the treatment using sole poultry manure (Figure 12). Sarker et al. (2001) observed that application of nitrogen increased grain and straw yields significantly.

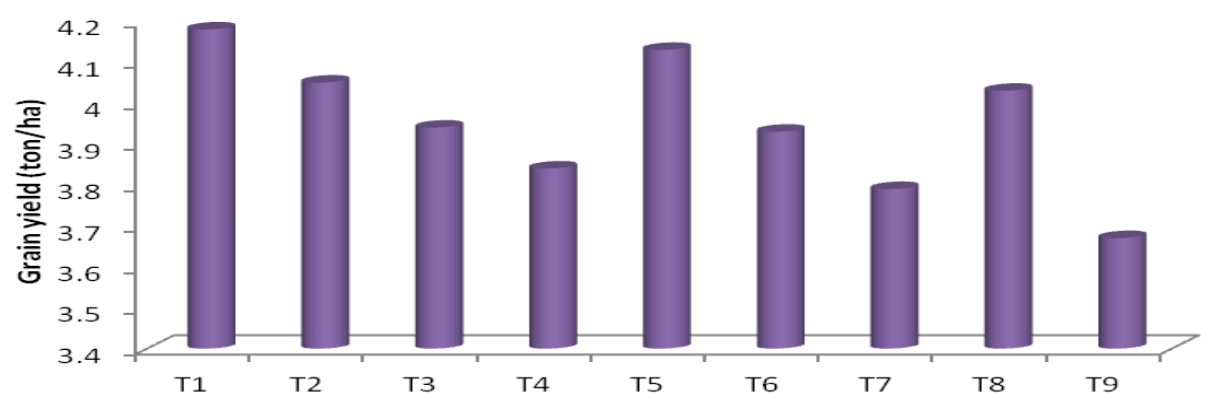

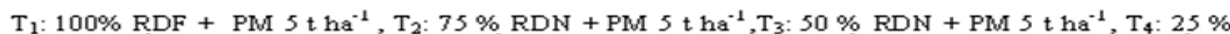
RDN + PM $5 \mathrm{tha}^{-1}, \mathrm{~T}_{5}: 75 \%$ RDS + PM $5 \mathrm{tha}^{-1}, \mathrm{~T}_{6}: 50 \%$ RDS + PM $5 \mathrm{tha}^{-1}, \mathrm{~T}_{7}: 25 \%$ RDS + PM $5 \mathrm{tha}^{-1}, \mathrm{~T}_{8}:$ $100 \%$ RDF, $\mathrm{T}_{9}$ : PM $5 \mathrm{tha}^{-1}$

Fig. 6. Effect of different combinations of organic and inorganic fertilizer on grain yield ( $\left.\mathrm{t} \mathrm{ha}^{-1}\right)$ of rice var. BRRI dhan33

\section{Chlorophyll content ( $\mathrm{mg} \mathrm{g}^{-1}$ fresh weight of leaf)}

The data on chlorophyll content ("a", "b" and total) of rice at different growth stages as influenced by organic and inorganic fertilizers in Table $1 \mathrm{a}, \mathrm{b}$ ). The chlorophyll "a" content at different growth stages (45, 60 and 75 DAT) differed significantly due to different treatments. Significantly higher chlorophyll "a" $\left(2.838,1.592\right.$ and $0.61 \mathrm{mg} \mathrm{g}^{-1}$ fresh weight of leaf respectively) was recorded in $\mathrm{T}_{1}$ while lowest chlorophyll "a" content from the treatment using sole poultry manure. Significantly higher chlorophyll "b" $\left(2.905,2.358\right.$ and $0.351 \mathrm{mg} \mathrm{g}^{-1}$ fresh weight of leaf respectively) was recorded in $\mathrm{T}_{1}$ (100\% Inorganic fertilizer +5 ton PM /ha). 
Effect of Poultry Manure Incorporated with $N$ and S Fertilizer on the Growth of Rice

Table 1(a). Effect of different combinations of organic and inorganic fertilizer on chlorophyll content of rice var. BRRI dhan33

\begin{tabular}{l|c|c|c|c|c|c}
\hline \multirow{2}{*}{ Treatments } & \multicolumn{3}{|c|}{ Chlorophyll a (mg g ${ }^{-1}$ fresh weight of leaf) } & \multicolumn{3}{c}{ Chlorophyll b(mg g ${ }^{-1}$ fresh weight of } \\
& $45 \mathrm{DAT}$ & $60 \mathrm{DAT}$ & $75 \mathrm{DAT}$ & $45 \mathrm{DAT}$ & $60 \mathrm{DAT}$ & $75 \mathrm{DAT}$ \\
\hline & $2.838 \mathrm{a}$ & $1.592 \mathrm{a}$ & $0.61 \mathrm{a}$ & $2.905 \mathrm{a}$ & $2.358 \mathrm{a}$ & $0.351 \mathrm{a}$ \\
$\mathrm{T}_{1}$ & $2.532 \mathrm{~b}$ & $1.428 \mathrm{~b}$ & $0.466 \mathrm{bc}$ & $2.496 \mathrm{bc}$ & $1.808 \mathrm{c}$ & $0.328 \mathrm{a}-\mathrm{c}$ \\
$\mathrm{T}_{2}$ & $2.458 \mathrm{bc}$ & $1.407 \mathrm{bc}$ & $0.452 \mathrm{bc}$ & $2.48 \mathrm{bc}$ & $1.504 \mathrm{~d}$ & $0.246 \mathrm{a}-\mathrm{c}$ \\
$\mathrm{T}_{3}$ & $2.406 \mathrm{~b}-\mathrm{d}$ & $1.383 \mathrm{bc}$ & $0.405 \mathrm{c}$ & $1.945 \mathrm{~d}$ & $1.23 \mathrm{e}$ & $0.21 \mathrm{c}$ \\
$\mathrm{T}_{4}$ & $2.427 \mathrm{~b}-\mathrm{d}$ & $1.438 \mathrm{~b}$ & $0.535 \mathrm{ab}$ & $2.341 \mathrm{c}$ & $1.749 \mathrm{c}$ & $0.299 \mathrm{a}-\mathrm{c}$ \\
$\mathrm{T}_{5}$ & $2.397 \mathrm{~b}-\mathrm{d}$ & $1.381 \mathrm{bc}$ & $0.534 \mathrm{ab}$ & $1.783 \mathrm{~d}$ & $1.563 \mathrm{~d}$ & $0.267 \mathrm{a}-\mathrm{c}$ \\
$\mathrm{T}_{6}$ & $2.318 \mathrm{~cd}$ & $1.374 \mathrm{bc}$ & $0.432 \mathrm{bc}$ & $1.571 \mathrm{e}$ & $1.474 \mathrm{~d}$ & $0.266 \mathrm{a}-\mathrm{c}$ \\
$\mathrm{T}_{7}$ & $2.339 \mathrm{~cd}$ & $1.378 \mathrm{bc}$ & $0.401 \mathrm{c}$ & $2.435 \mathrm{bc}$ & $1.76 \mathrm{c}$ & $0.299 \mathrm{a}-\mathrm{c}$ \\
$\mathrm{T}_{8}$ & $2.301 \mathrm{~d}$ & $1.311 \mathrm{c}$ & $0.369 \mathrm{c}$ & $1.402 \mathrm{e}$ & $1.219 \mathrm{e}$ & $0.226 \mathrm{bc}$ \\
$\mathrm{T}_{9}$ & 0.1394 & 0.1061 & 0.1153 & 0.1781 & 0.1394 & 0.1104 \\
$\mathrm{LSD}_{0.05}$ & 3.01 & 2.54 & 1.987 & 3.25 & 1.69 & 5.13 \\
$\mathrm{CV}_{0}$ & &
\end{tabular}

Table 1(b). Effect of different combinations of organic and inorganic fertilizer on chlorophyll content (total) of rice var. BRRI dhan33

\begin{tabular}{l|c|c|c}
\hline \multirow{2}{*}{ Treatments } & \multicolumn{3}{|c}{ Total chlorophyll (mg g $\mathrm{m}^{-1}$ fresh weight of leaf) } \\
\cline { 2 - 4 } & $45 \mathrm{DAS}$ & $60 \mathrm{DAS}$ & $75 \mathrm{DAS}$ \\
\hline $\mathrm{T}_{1}$ & $5.382 \mathrm{a}$ & $3.797 \mathrm{a}$ & $0.961 \mathrm{a}$ \\
$\mathrm{T}_{2}$ & $5.028 \mathrm{~b}$ & $3.236 \mathrm{~b}$ & $0.794 \mathrm{a}-\mathrm{c}$ \\
$\mathrm{T}_{3}$ & $4.938 \mathrm{bc}$ & $2.911 \mathrm{~cd}$ & $0.698 \mathrm{bc}$ \\
$\mathrm{T}_{4}$ & $4.351 \mathrm{~d}$ & $2.613 \mathrm{e}$ & $0.615 \mathrm{bc}$ \\
$\mathrm{T}_{5}$ & $4.768 \mathrm{c}$ & $3.247 \mathrm{~b}$ & $0.834 \mathrm{ab}$ \\
$\mathrm{T}_{6}$ & $4.18 \mathrm{~d}$ & $2.944 \mathrm{~cd}$ & $0.801 \mathrm{a}-\mathrm{c}$ \\
$\mathrm{T}_{7}$ & $3.889 \mathrm{e}$ & $2.848 \mathrm{~d}$ & $0.698 \mathrm{bc}$ \\
$\mathrm{T}_{8}$ & $4.774 \mathrm{c}$ & $3.138 \mathrm{bc}$ & $0.7 \mathrm{bc}$ \\
$\mathrm{T}_{9}$ & $3.703 \mathrm{f}$ & $2.53 \mathrm{e}$ & $0.595 \mathrm{c}$ \\
\hline $\mathrm{LSD}(0.05)$ & 0.17 & 0.23 & 0.19 \\
$\mathrm{CV}(\%)$ & 3.57 & 2.91 & 3.39 \\
\hline
\end{tabular}

\section{$\mathrm{N}$ content in grain}

$\mathrm{N}$ content in grain (\%) differed significantly among the different combinations of organic and inorganic fertilizer (Figure 13). Significantly higher $\mathrm{N}$ content in grain (1.28\%) was recorded in $\mathrm{T}_{1}$ and lowest $\mathrm{N}$ content in grain (1.10\%) from the treatment using poultry manure only.

\section{$\mathrm{S}$ content in grain (\%)}

Significantly higher $S$ content $(0.47 \%)$ was recorded in $T_{5}$ and lowest $S$ content $(0.183 \%)$ was found from the treatment using poultry manure only (Fig. 14). Bari et al. (2013) was also found that nutrient content in grain increased while organic manure combined with inorganic fertilizers. 
Sarker et al.

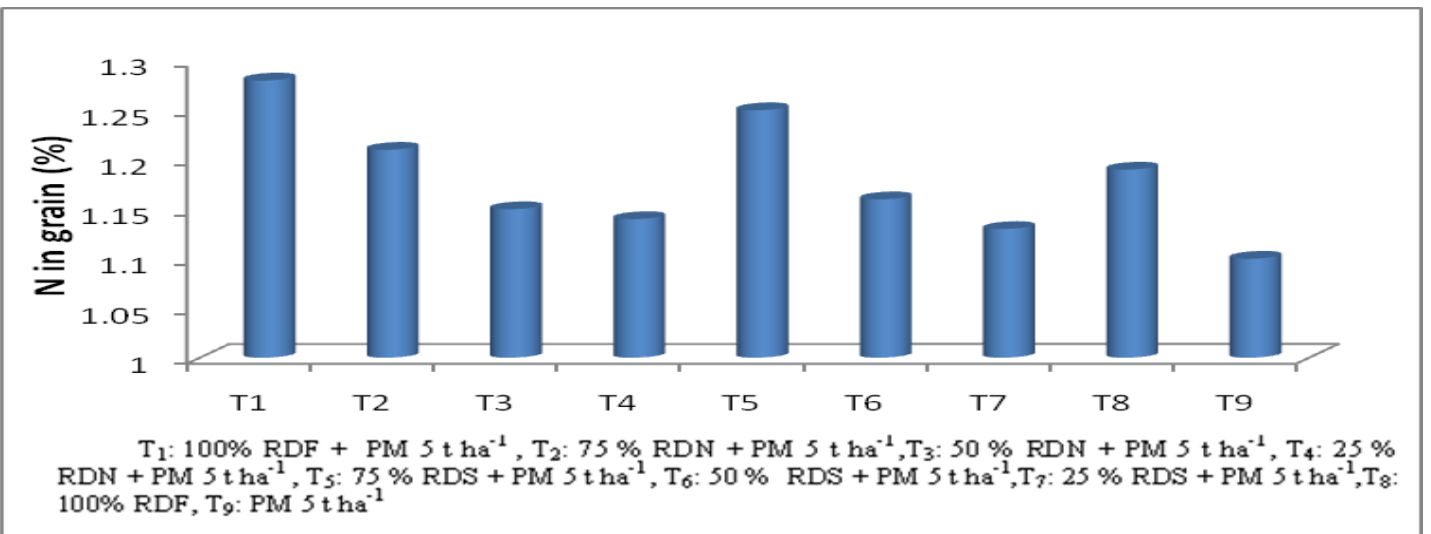

Fig.7. Effect of different combinations of organic and inorganic fertilizer on $\mathrm{N}$ content in grain (\%) of BRRI dhan33

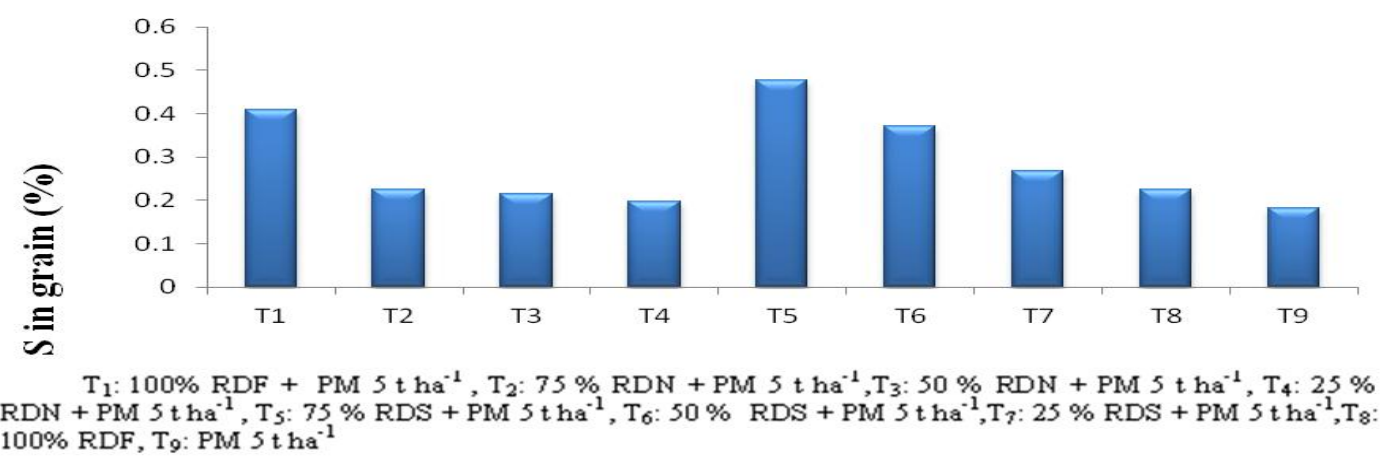

Fig. 8. Effect of different combinations of organic and inorganic fertilizer on $\mathrm{S}$ content in grain (\%) of BRRI dhan33

\section{$\mathrm{N}$ content in straw (\%)}

$\mathrm{N}$ content in straw (\%) differed significantly among the different combinations of organic and inorganic fertilizer (Figure 4.15). Significantly higher $N$ content $(0.351 \%)$ was recorded in $T_{1}$ which was closely followed by $\mathrm{T}_{5}(0.334 \%)$. Lowest $\mathrm{N}$ content $(0.286 \%)$ was found from the treatment using poultry manure only. These results have the conformity with the results of Bari et al. (2013).

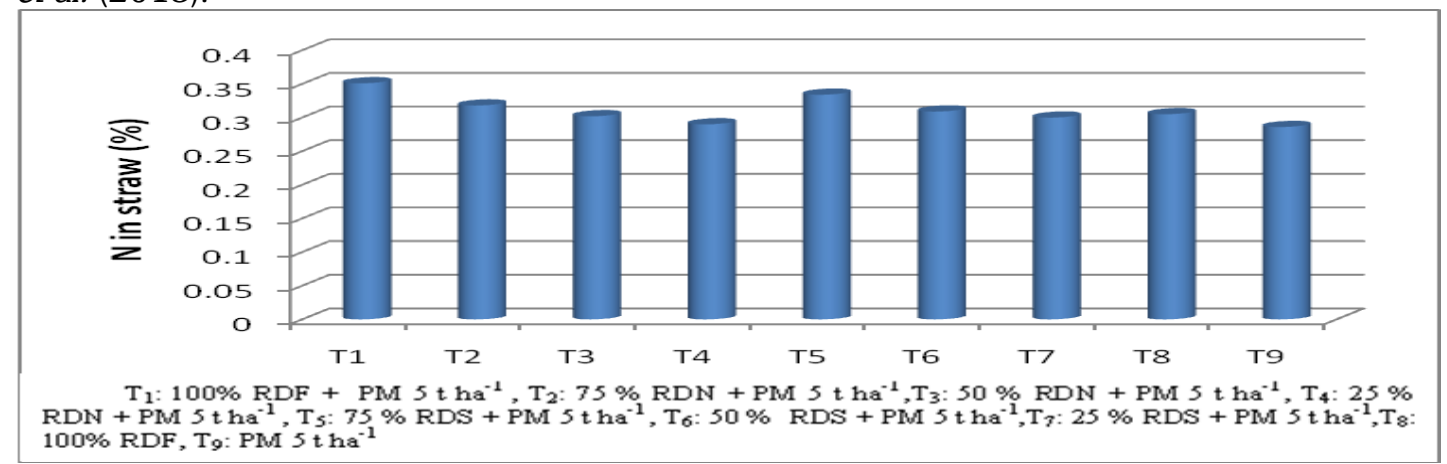

Fig. 9. Effect of different combinations of organic and inorganic fertilizer on $\mathrm{N}$ content in straw (\%) of BRRI dhan33 


\section{$\mathrm{P}$ content in straw (\%)}

$\mathrm{P}$ content in straw (\%) differed insignificantly among the different combinations of organic and inorganic fertilizer (Figure 16). Though higher $\mathrm{P}$ content $(0.213 \%)$ was recorded in $\mathrm{T}_{5}$ which was closely followed by $\mathrm{T}_{1}(0.195 \%)$. Lowest $\mathrm{P}$ content $(0.146 \%)$ was found from the treatment using poultry manure only. These results agree with the results of Bari et al. (2013).

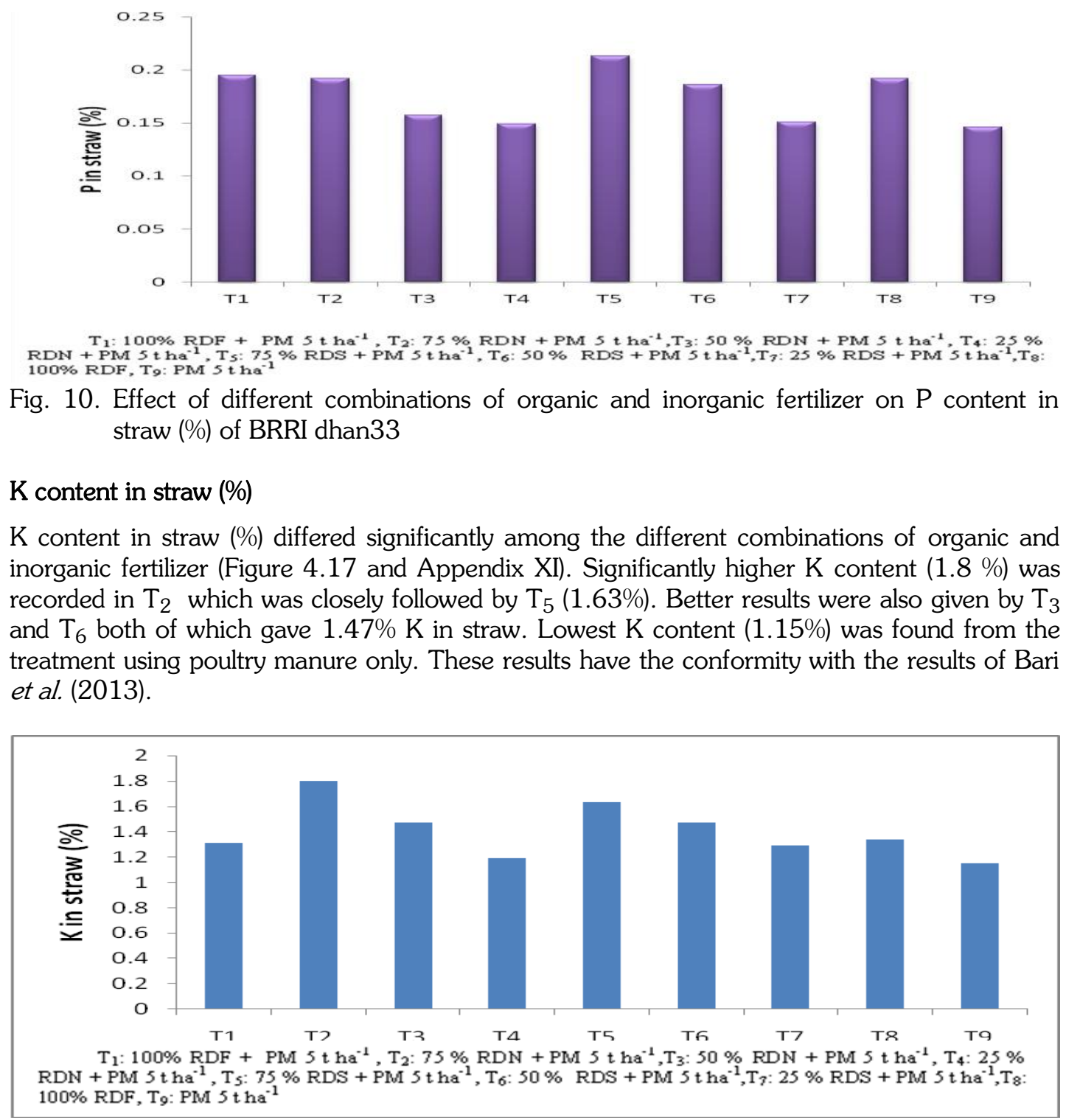

Fig. 11. Effect of different combinations of organic and inorganic fertilizer on $\mathrm{K}$ content in straw (\%) of BRRI dhan33

\section{S content in straw (\%)}

$\mathrm{S}$ content in straw (\%) differed significantly among the different combinations of organic and inorganic fertilizer (Fig. 18). Significantly higher S content in straw (0.293\%) was recorded in 
Sarker et al.

$\mathrm{T}_{5}$ and lowest $\mathrm{S}$ content in straw $(0.149 \%)$ was found from the treatment using poultry manure only. These results have the conformity with the results of Bari et al. (2013).

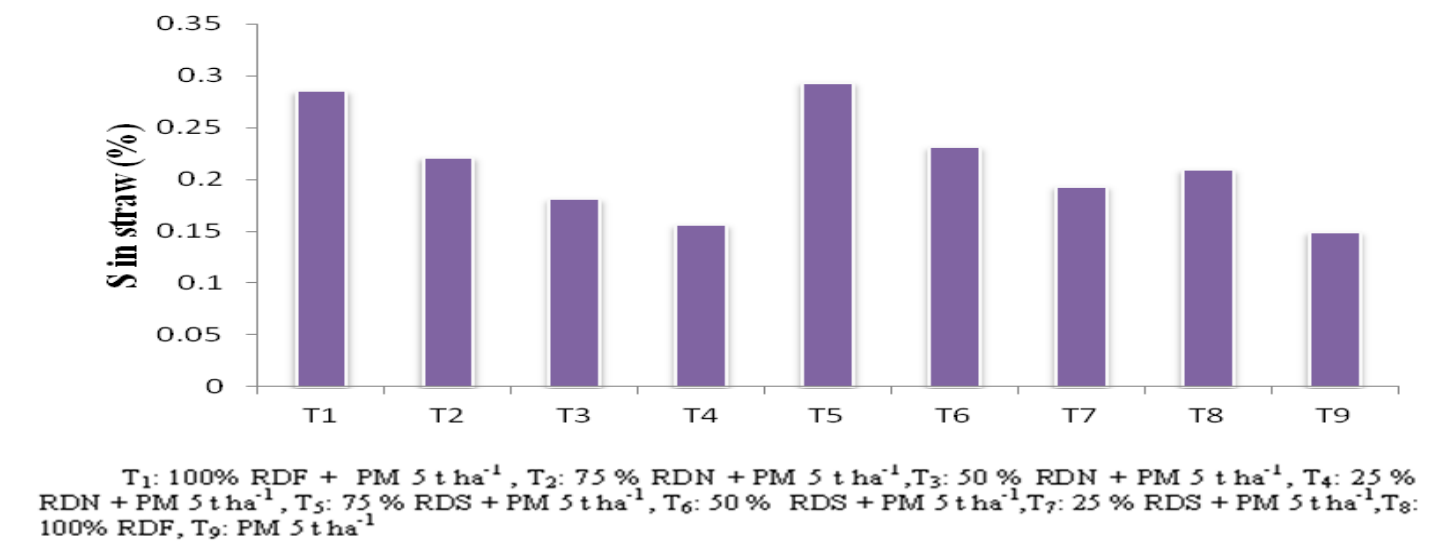

Fig. 12. Effect of different combinations of organic and inorganic fertilizer on $\mathrm{S}$ content in straw (\%) of BRRI dhan33

\section{Conclusion}

Significant variation was found in growth and yield parameters as well as in chlorophyll content and nutrient content of aman rice due to the various combinations of organic and inorganic fertilizers. The treatment of $100 \%$ Inorganic fertilizer +5 ton poultry manure /ha could give the maximum growth, yield, chlorophyll and nutrient contents of rice var. BRRI dhan33.

\section{References}

Amin, M., M.A. Khan, E.A. Khan, E. A. and M. Ramzan. 2004. Effect Of Increased Plant Density And Fertilizer Dose On The Yield Of Rice Variety Ir-6. J. Res. Sci. 15(1), 09-16.

Bari, A.S.M.F., M A. Khan, S. Sultana, M. Hasanuzzaman, N. Sultana. 2013. Effect Of Various Inorganic Fertilizer And Manure With Different Water Managements On Yield And Yield Attributes Of Boro Rice. J. Expt. Biosci. 4 (2): 1-6.

Brady, N. C. 1999. The nature and properties of soils. Prentice Hall of India Pvt. Ltd. Delhi.

Channabasavanna, A. S. 2003. Efficient utilization of poultry manure with inorganic fertilizer in wet land rice. J. Maharashtra Agric. Univer. 27(3): 237-238.

FAO (Food and Agricultural Organization). (1999). Yearbook of Production, FAO Statistics Division. 605-607.

Hegde, D. M. and S. N. Sudhakara Babu. 2007. Correcting sulphur deficiencies in soils and crops. Indian J. Fert. 3(1): 65-79.

Jackson, M L. 1973. Soil chemical analysis. Prentice-Hall of India, Pvt. Ltd.. pp. 326-338.

Maynard, A.A. 1984. Sustained vegetable production for three years using composted animal manures. J. Am. Soc. Horti. Sci. 94(3): 88-96.

Meelu, O. P. and Yadvinder Singh. 1991. Integrated use of fertilizers and organic manure for higher returns. Prog. Fmg. Punjab Agric. Univ. 27: 3-4. 
Effect of Poultry Manure Incorporated with $N$ and S Fertilizer on the Growth of Rice

Nambiar, K. K. M. 1991. Long-term fertility effects on wheat productivity. In wheat for the Nontraditional Warm areas, Saunders D.A. ed., CIMMYT. pp 516-521.

Ndaeyo, N.U., K.U. Iboko, G. I. Harry, and S. O. Edem. (2008). Growth and yield performances of some upland rice (oryza sativa l.) Cultivars as influenced by varied rates of NPK (15:15:15) fertilizer on an ultisol. J. Trop. Agric. Food. Env. Ext. 7 (3): 249 - 255.

Russell DF (1986) MSTAT-C Pakage Programme. Crop and Soil Science Department, Michigan Univ, USA.

Sadaphal, M. N., A. Dayanand and T. Singh. 1981. relative efficieny of different grades of urea and nitrogen rates for rice. Indian J. Agron. 26 (4): 428-431.

Saha, P.K., M.A. Saleque, G.M. Panaullah, and M.A. Mazid Miah. (2004). Comparison of the fertilizer recommendation Models for low land rice. Bangladesh J. Soil Sci. 30 (1-2): 31-37.

Sarker, A. B. S., N. Kojims and Amano, Y. 2001. Effect of nitrogen rates on Japonica and Indica rice under irrigated Ecosystem. Bangladesh J. Sci. and Tenhol. 3(1): 49-58.

Sarvanan, A., V. Velu, and K.M. Ramanath, 1987. Effect of combined application of bioorganic and chemical fertilizers on physical properties, nitrogen transformation and yield of rice in submerged soils. Oryza: 1-6.

Singh, C. S. and U. N. Singh. 2002. Effect of nitrogen and sulphur nutrition on growth and yield of rice (Oryza sativa L.) cultivars. Res. Crops. 3(3): 645-646. 